\title{
Diagnosis of macronutrient deficiency in Erythroph- leum fordii, a nitrogen-fixing rosewood species
}

\author{
Z.G. Zhao, K.Q. Lin, J.J. Guo, J. Zeng
}

\begin{abstract}
Zhao Z.G., Lin K.Q., Guo J.J., Zeng J., 2015. Diagnosis of macronutrient deficiency in Erythrophleum fordii, a nitrogen-fixing rosewood species. Ann. For. Res. 58(1):
\end{abstract} $15-26$.

Abstract. Erythrophleum fordii (Caesalpiniaceae; nitrogen fixing species) is one of traditional rosewood species indigenous to Southeast Asia and southern China. Slow growth and symptoms such as leaf discoloration, curling and defoliation were usually observed in the nursery and its young plantations due perhaps to deficiencies of specific nutrients. Here sand culture experiment was conducted for its seedlings to assess their visual foliar symptoms, growth performance and nutrient interaction in response to six macronutrient deficiencies. Leaves of E. fordii seedlings discolored in all treatments of nutrient deficiency, and sizes of both old and young leaves became small under nitrogen $(\mathrm{N})$ deficiency, while only young leaves grew small under deficiencies of calcium $(\mathrm{Ca})$ and sulphur $(\mathrm{S})$. Seedling growth was inhibited significantly under deficiencies of $\mathrm{N}$, potassium $(\mathrm{K})$ and phosphorus $(\mathrm{P})$ except that $\mathrm{P}$ deficiency increased diameter at root collar. The difference of seedling $\mathrm{N}$ concentration between $-\mathrm{N}$ and control was normally much smaller than those for other nutrient elements because $-\mathrm{N}$ seedling could acquire $\mathrm{N}$ by nitrogen fixation of nodules under $\mathrm{N}$ deficiency. In spite of this, $\mathrm{N}$ was still major limiting factor for plant growth under $\mathrm{N}$ deficiency. Besides in $\mathrm{P}$ deficiency, $\mathrm{P}$ was also the major limiting factor under deficiencies of magnesium $(\mathrm{Mg}), \mathrm{Ca}$ and $\mathrm{S}$, which indicated that $\mathrm{P}$ play an important role in nutrient demand and balance for E. fordii. Antagonism or synergism occurred widely between six macronutrients, especially for $\mathrm{P}, \mathrm{K}$ and $\mathrm{Ca}$, their concentrations increased or decreased in all six deficiency treatments in comparison with the control. The implications of these findings were also discussed with a case study on nutritional diagnosis for a young plantation of this species. Keywords Erythrophleum fordii Oliv., growth performance, leaf morphology, leaf nutrient interaction, macronutrient deficiency, nitrogen-fixing tree species.

Authors. Zhi-Gang Zhao, Kai-Qin Lin, Jun-Jie Guo, Jie Zeng (zengdasan@hotmail.com) - Research Institute of Tropical Forestry, CAF, Longdong, Guangzhou 510520, Guangdong, China.

Manuscript received November 20, 2014; revised December 16, 2014; accepted December 23, 2014; online first December 30, 2014. 


\section{Introduction}

Erythrophleum fordii (Caesalpiniaceae) is one of traditional rosewood species indigenous to Southeast Asia and southern China, its wood has been mainly used in shipbuilding, construction, carving and furniture making for several hundred years (Nghia 2004, Zhao et al. 2009). Currently, E. fordii has been widely planted in southern China so as to meet the rapidly growing demand for high quality wood or wood products. E. fordii is also a nitrogenfixing tree species, its roots can be infected by a kind of rhizobium identified as Bradyrhizobium elkanii and can produce nodules ( $\mathrm{Lu}$ et al. 2011, Yao et al. 2014), it thus has special ability to improve tree growth and nutrition under nutrient limiting conditions (Mortimer et al. 2013), and restore or maintain soil fertility in forest systems (Danso et al. 2002, Scheublin et al. 2004). Therefore it is also used in establishment of ecological forests for common welfare. However, leaf symptoms such as leaf discoloration, curling and heavy defoliation were usually observed in young plantations of E. fordii (Figure 1). Meanwhile, some leaf symptoms were also observed in the nursery. As confirmed in a number of studies on plant species, plant growth and leaf symptoms are in general associated with specific soil nutrients deficiencies (Yeh et al. 2000, Ares et al. 2003, Davis et al. 2011).
The nutrient deficiency, in particular macronutrient deficiency, can not only inhibit the growth of trees, but also affect their disease tolerance or their resistance to pathogens (Walters \& Bingham 2007, Chen et al. 2010, Ouimet et al. 2013), thus reduce severely the stability and expected economic benefits of the plantations. Up to present, no information has been reported on nutrient deficiency diagnosis for E. fordii, even for Erythrophleum genus although a number of tree species have been studied in this field. However, tree species were usually specific in their nutrient demands and nutrient use efficiency (Bigelow \& Canham 2007, Chen et al. 2012, Millner \& Kemp 2012), and interactions among nutrient elements such as antagonism, compensate etc. were even complicated. Additionally, root nodules appear to contribute to plant resilience to nutrient deficiencies in nitrogen-fixing tree species (Schulze et al. 2006). The response of $E$. fordii to nutrient deficiencies should therefore be determined, which is useful to achieve reasonable fertilization management in nursery and plantations for this species.

The objective of the present study is to identify the response of $E$. fordii seedlings to six macronutrient elements deficiencies, nitrogen $(\mathrm{N})$, phosphorus $(\mathrm{P})$, potassium $(\mathrm{K})$, calcium $(\mathrm{Ca})$, magnesium $(\mathrm{Mg})$ and sulphur $(\mathrm{S})$ by sand culture trial, in terms of morphological characterizations, growth performances and

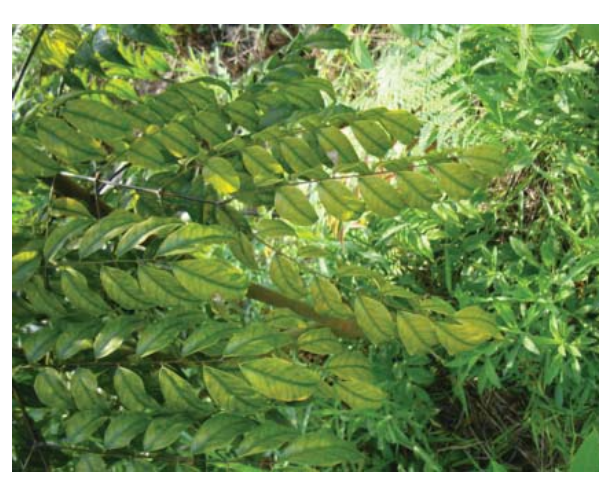

Leaf chlorosis

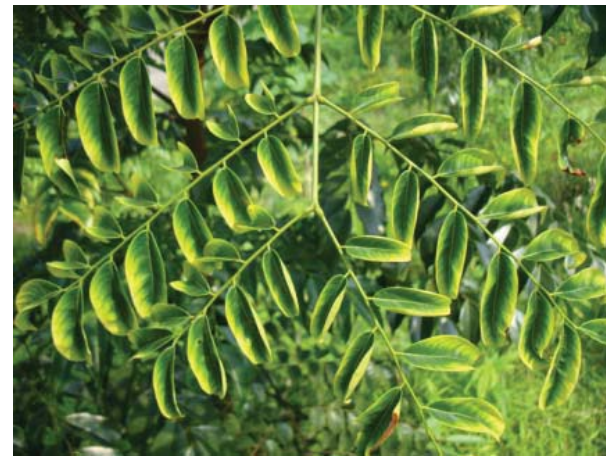

Leaf curling

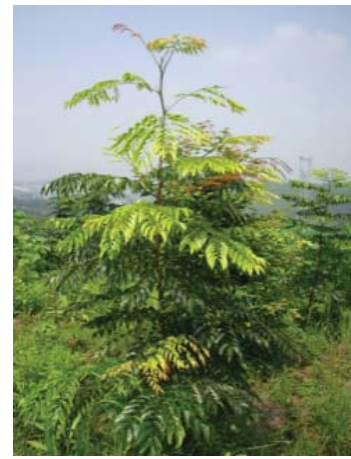

Defoliation

Figure 1 Leaf chlorosis, curling and defoliation in the young plantation of Erythrophleum fordii at Shaoguan City, Guangdong Province, China 
leaf nutrient interaction. As mentioned above, observed at Shaoguan, Guangdong Province, China was a piece of $E$. fordii young plantation in which almost all the trees exhibited leaf symptoms of nutrient deficiencies, we also attempt to apply the findings to assess the nutrient status for this plantation as a case study through comparative analysis on saplings in the plantation and seedlings in the sand culture trial, and discuss the potential to extend nutritional diagnosis in nursery to young plantations so as to guide the nutritional management of $E$. fordii plantations.

\section{Materials and methods}

\section{Seedling sand culture for nutrient deficiency}

A sand culture trial was conducted in the ventilated greenhouse at the Research Institute of Tropical Forestry, Chinese Academy of Forestry (RITF; $23^{\circ} 11^{\prime} 28^{\prime \prime} \mathrm{N}, 113^{\circ} 22^{\prime} 44^{\prime \prime} \mathrm{E}$ ), Guangzhou, China. Healthy seedlings of $E$. fordii which had two pinnately compound leaves with similar height of $10.48 \pm 0.25 \mathrm{~cm}$ and diameter at root collar of $2.68 \pm 0.04 \mathrm{~mm}$ were selected and transplanted into plastic pots $(18 \times 13 \times 16 \mathrm{~cm})$ filled with equal weight of 1 $2 \mathrm{~mm}$ diameter grain quartz sands in $8^{\text {th }}$ June, 2011. These seedlings were grown in the nursery of RITF with seeds collected from a mother tree in a natural forest of E. Fordii located at Damingshan Mountain, Wuming County, Guangxi. The sands should be washed with tap water, soaked in $1 \% \mathrm{HCl}$ for $24 \mathrm{~h}$ to remove nutrient residues, rinsed with deionized water and finally wind-dried, and each pot was filled with $1.4 \mathrm{Kg}$ sands. Before transplantation, the seedlings should also be washed with tap water and rinsed with deionized water. The initial irrigation regime was measured by the method of Chen et al. (2010) and the real irrigation regime was adjusted by the seedling growth demand and weather condition afterward. The mean day/night temperature was $30 / 25^{\circ} \mathrm{C}$ and relative humility ranged from 50 to $70 \%$ in the greenhouse during the study period.

The nutrient deficiency treatments started two weeks after transplanting when the seedlings established well in the sands. The randomized completed block design was implemented with four blocks and seven treatments/block including minus nitrogen $(-\mathrm{N})$, minus phosphorus $(-\mathrm{P})$, minus potassium $(-\mathrm{K})$, minus calcium $(-$ $\mathrm{Ca})$, minus magnesium $(-\mathrm{Mg})$, minus sulphur $(-\mathrm{S})$ nutrient solutions, and complete nutrient mix as a control, and with 15 seedlings in each plot and totally 420 seedlings in all treatments. The chemical compositions of relevant nutrient solutions for these treatments were shown in Table 1; half-strength nutrient solutions were supplied with $50 \mathrm{ml}$ for each seedlings every 10 days during the former 60 days, and full-strength thereafter.

As E. fordii seedlings were often grown in this greenhouse, this perhaps increased the chance for $E$. fordii roots infected by Bradyrhizobium elkanii which is widely distributed in southern China (Lu et al. 2011). The positions of pots were changed twice every month randomly to reduce the edge effects and make the infection chance of seedlings equivalent during the study period. The trial lasted 150 days until foliar symptoms were fully exhibited.

Visual leaf symptoms of the seedlings were recorded and photographed when necessary over the period of the trial. The root collar diameter and height of all the seedlings were measured every three weeks after treatments. Five seedlings per plot were randomly selected for leaf and root nodule biomass measurement at the end of the trial, and completely developed leaves on the top of seedlings were also sampled for nutrient measurement. These leaf samples were oven dried at $65{ }^{\circ} \mathrm{C}$ for $48 \mathrm{~h}$, and then were ground, digested in a block digester using a $\mathrm{H}_{2} \mathrm{SO}_{4}$ and $\mathrm{K}_{2} \mathrm{SO}_{4}$ - $\mathrm{CuSO}_{4}$ mixture catalyst for total $\mathrm{N}$ by Kjeldahl digestion-diffusion method, while $\mathrm{HNO}_{3}-\mathrm{HClO}_{4}$ mixture solution for $\mathrm{P}$ by Mo-Sb colorimetry and for $\mathrm{K}$ by flame photometer method, for $\mathrm{Ca}, \mathrm{Mg}$ and $\mathrm{S}$ by ICP 
Table 1 Chemical compositions $\left(\mathrm{mL} \cdot \mathrm{L}^{-1}\right)$ of complete and six macronutrient- deficient nutrient solutions

\begin{tabular}{|c|c|c|c|c|c|c|c|}
\hline Sources & Control & $-\mathrm{N}$ & $-\mathrm{P}$ & $-\mathrm{K}$ & $-\mathrm{Ca}$ & $-\mathrm{Mg}$ & $-\mathrm{S}$ \\
\hline $1 \mathrm{~mol} \cdot \mathrm{L}^{-1} \mathrm{KNO}_{3}$ & 5 & 1 & 6 & 1 & 5 & 6 & 6 \\
\hline $1 \mathrm{~mol} \cdot \mathrm{L}^{-1} \mathrm{Ca}\left(\mathrm{NO}_{3}\right)_{2} \cdot 4 \mathrm{H}_{2} \mathrm{O}$ & 5 & / & 4 & 5 & / & 4 & 4 \\
\hline $1 \mathrm{~mol} \cdot \mathrm{L}^{-1} \mathrm{MgSO}_{4}$ & 2 & 2 & 2 & 2 & 2 & / & l \\
\hline $1 \mathrm{~mol} \cdot \mathrm{L}^{-1} \mathrm{KH}_{2} \mathrm{PO}_{4}^{4}$ & 1 & l & / & $\bar{l}$ & 1 & 1 & 1 \\
\hline $0.5 \mathrm{~mol} \cdot \mathrm{L}^{-1} \mathrm{~K}_{2}^{2} \mathrm{SO}_{4}^{4}$ & / & 5 & l & l & / & 3 & l \\
\hline $0.5 \mathrm{~mol} \cdot \mathrm{L}^{-1} \mathrm{CaCl}_{2}^{4}$ & / & 10 & / & 10 & / & / & I \\
\hline $1 \mathrm{~mol} \cdot \mathrm{L}^{-1} \mathrm{NaH}_{2} \mathrm{PO}_{2} \cdot 2 \mathrm{H}_{2} \mathrm{O}$ & / & 10 & / & 10 & / & / & / \\
\hline $0.01 \mathrm{~mol} \cdot \mathrm{L}^{-1} \mathrm{CaSO}_{4}^{2} \cdot 2 \mathrm{H}_{2}^{2} \mathrm{O}$ & / & 20 & / & / & / & / & / \\
\hline $1 \mathrm{~mol} \cdot \mathrm{L}^{-1} \mathrm{Mg}\left(\mathrm{NO}_{3}\right)_{2}^{4} \cdot 6 \mathrm{H}_{2}^{2} \mathrm{O}$ & / & / & I & I & I & / & 2 \\
\hline $0.05 \mathrm{~mol} \cdot \mathrm{L}^{-1} \mathrm{Fe}-\mathrm{EDTA}$ & 2 & 2 & 2 & 2 & 2 & 2 & 2 \\
\hline Arnon micronutrient solutions & 1 & 1 & 1 & 1 & 1 & 1 & 1 \\
\hline
\end{tabular}

(Vista-MPX CCD Simultaneous ICP-OES, Varian Inc.).

\section{Diagnosis on nutrient deficiency of young plantation}

A three-year-old $E$. fordii plantation was investigated at Shaoguan $\left(24^{\circ} 51^{\prime} \mathrm{N}, 13^{\circ} 33^{\prime} \mathrm{E}\right)$, Guangdong Province, China, the soil is slopedeposited red soil which developed from sandshale, and almost all saplings exhibited foliar symptoms of nutrient deficiencies. Young and old leaves with typical symptoms were sampled separately from ten saplings, and nutrient measurements of these samples were conducted with the same methods as mentioned above.

The soils were also sampled at three depths: 0-10, 10-30 and 30-60 cm near each sapling. The samples were analyzed normally for: $\mathrm{pH}$ by acidometer method with their leaching solutions (soil: water $=1: 2.5$ ); total $\mathrm{N}$ by the same method as leaf mentioned above; available $\mathrm{N}$ by diffusion method, total $\mathrm{P}$ by Mo$\mathrm{Sb}$ colorimetry method and total $\mathrm{K}$ by flame photometer method after melted with $\mathrm{NaOH}$; available $\mathrm{P}$ by $\mathrm{Mo}-\mathrm{Sb}$ colorimetry after $\mathrm{HCl}$ $\mathrm{H}_{2} \mathrm{SO}_{4}$ extraction; available $\mathrm{K}$ by flame photometer method, exchangeable $\mathrm{Ca}, \mathrm{Mg}$ by ICP after $\mathrm{CH}_{3} \mathrm{COONH}_{4}$ extraction; total $\mathrm{S}$ by ICP after digestion with $\mathrm{Mg}\left(\mathrm{NO}_{3}\right)_{2}$; and soluble $\mathrm{S}$ by ICP with water extraction (soil : water $=1$ : 5). The chemical characteristics of the soils were shown in Table 2.

\section{Statistical analysis}

A one-way analysis of variance (ANOVA) was performed to test difference in growth performance and leaf nutrient status among treatments, and Dunnett's tests were further conducted for comparing each nutrient deficiency treatment with control $(P<0.05)$. Paired-samples tests for young and old leaf nutrient status in young plantation were also applied simultaneously. Data of percentage were transformed into arc tangent before ANOVA. All data analyses were conducted using SPSS 11.5.

\section{Results}

\section{Visual foliar symptoms on seedlings}

The results of visual foliar symptoms on $E$. fordii seedlings were summarized in Table 3 for all macronutrient deficiency treatments, mainly including changes of leaf color and size, and occurrence of necrotic spotting. Among these treatments, the foliar symptoms for $\mathrm{N}$ deficiency was the most obvious, all leaves of $-\mathrm{N}$ seedlings were smaller-sized than those in control 
Table 2 Soil chemical characteristics in Erythrophleum fordii plantation. Soils at 5 points were sampled in the plantation with area of 1.3 hectare

\begin{tabular}{|c|c|c|c|c|c|c|c|c|c|c|c|c|}
\hline \multirow{2}{*}{$\begin{array}{l}\text { Soil } \\
\text { layer } \\
(\mathrm{cm})\end{array}$} & \multirow[t]{2}{*}{$\mathrm{pH}$} & otal N & Total P & Total K & Avail. N & Avail. P & Avail. K & Exch. Ca & $\begin{array}{l}\text { Exch. } \\
\mathrm{Mg}\end{array}$ & $\begin{array}{c}\text { Exch. } \\
\mathrm{Al}\end{array}$ & \multirow{2}{*}{$\begin{array}{l}\text { Total S } \\
\mathrm{g} \cdot \mathrm{kg}^{-1}\end{array}$} & \multirow{2}{*}{$\begin{array}{l}\text { Soluble } \\
\mathrm{SO}_{4}^{2-} \\
\mathrm{mg} \cdot \mathrm{kg}^{-1}\end{array}$} \\
\hline & & \multicolumn{3}{|c|}{$\mathrm{g} \cdot \mathrm{kg}^{-1}$} & \multicolumn{3}{|c|}{$\mathrm{mg} \cdot \mathrm{kg}^{-1}$} & \multicolumn{3}{|c|}{$\operatorname{cmol}(+) \cdot \mathrm{kg}^{-1}$} & & \\
\hline $0-10$ & $\begin{array}{c}4.33 \\
( \pm 0.13)\end{array}$ & $\begin{array}{c}1.09 \\
( \pm 0.13)\end{array}$ & $\begin{array}{c}0.27 \\
( \pm 0.01)\end{array}$ & $\begin{array}{c}14.93 \\
( \pm 6.63)\end{array}$ & & $\begin{array}{c}1.66 \\
( \pm 0.58)\end{array}$ & $\begin{array}{c}61.27 \\
( \pm 17.12)\end{array}$ & $\begin{array}{c}0.03 \\
( \pm 0.005)\end{array}$ & $\begin{array}{c}0.11 \\
( \pm 0.02)\end{array}$ & $\begin{array}{c}4.57 \\
( \pm 0.11)\end{array}$ & $\begin{array}{c}0.13 \\
( \pm 0.02)\end{array}$ & $\begin{array}{c}13.01 \\
( \pm 7.27)\end{array}$ \\
\hline $10-30$ & $\begin{array}{c}4.29 \\
( \pm 0.08)\end{array}$ & $\begin{array}{c}0.75 \\
( \pm 0.09)\end{array}$ & $\begin{array}{c}0.26 \\
( \pm 0.03)\end{array}$ & $\begin{array}{c}16.85 \\
( \pm 7.10)\end{array}$ & $\begin{array}{l}50.0 \\
( \pm 14 .\end{array}$ & $\begin{array}{c}0.73 \\
( \pm 0.13)\end{array}$ & $\begin{array}{c}45.27 \\
( \pm 10.58)\end{array}$ & $\begin{array}{c}0.02 \\
( \pm 0.002)\end{array}$ & $\begin{array}{c}0.08 \\
( \pm 0.01)\end{array}$ & $\begin{array}{c}3.39 \\
( \pm 0.13)\end{array}$ & $\begin{array}{c}0.09 \\
( \pm 0.01)\end{array}$ & $\begin{array}{c}23.35 \\
( \pm 6.03)\end{array}$ \\
\hline $30-60$ & $\begin{array}{c}4.29 \\
( \pm 0.03)\end{array}$ & $\begin{array}{c}0.64 \\
( \pm 0.04)\end{array}$ & $\begin{array}{c}0.27 \\
( \pm 0.03)\end{array}$ & $\begin{array}{c}23.46 \\
( \pm 11.84)\end{array}$ & $\begin{array}{c}48.51 \\
( \pm 18.71)\end{array}$ & $\begin{array}{c}0.50 \\
( \pm 0.14)\end{array}$ & $\begin{array}{c}43.27 \\
( \pm 16.91)\end{array}$ & $\begin{array}{c}0.02 \\
( \pm 0.002)\end{array}$ & $\begin{array}{c}0.08 \\
( \pm 0.02)\end{array}$ & $\begin{array}{c}3.26 \\
( \pm 0.15)\end{array}$ & $\begin{array}{c}0.10 \\
( \pm 0.01)\end{array}$ & $\begin{array}{c}28.00 \\
( \pm 5.12)\end{array}$ \\
\hline
\end{tabular}

Note. In paranthesis is the standard deviation.

Table 3 Foliar symptom description of macronutrient deficiency in Erythrophleum fordii seedlings

\begin{tabular}{|c|c|c|c|c|c|}
\hline $\begin{array}{l}\text { Nutrient } \\
\text { deficiency }\end{array}$ & Position & Discoloration & Size & Distortion & Necrotic spotting \\
\hline \multirow[t]{2}{*}{$-\mathrm{N}$} & Young leaf & Light green/yellow & Smaller & Leaf tip rolled downward & No \\
\hline & Old leaf & Light green/yellow & Smaller & Leaf tip rolled downward & No \\
\hline \multirow[t]{2}{*}{$-\mathrm{P}$} & Young leaf & Light green & Normal & Leaf tip rolled downward & No \\
\hline & Old leaf & Dark green & Normal & Leaf tip rolled downward & $\begin{array}{l}\text { Central edges of } \\
\text { leaflets }\end{array}$ \\
\hline \multirow[t]{2}{*}{$-\mathrm{K}$} & Young leaf & $\begin{array}{l}\text { Interveinal chlorosis, } \\
\text { saddle-backing }\end{array}$ & Smaller & Leaf margins warped & No \\
\hline & Old leaf & $\begin{array}{l}\text { Chlorosis from leaf tip } \\
\text { to base }\end{array}$ & Normal & Leaf margins warped & $\begin{array}{l}\text { Leaf tip withered, } \\
\text { then margin } \\
\text { severely }\end{array}$ \\
\hline \multirow[t]{2}{*}{$-\mathrm{Ca}$} & Young leaf & $\begin{array}{l}\text { Chlorosis from leaf tip } \\
\text { to base }\end{array}$ & Smaller & $\begin{array}{l}\text { Leaf margins rolled } \\
\text { upward }\end{array}$ & No \\
\hline & Old leaf & Interveinal light green & Normal & Leaf margins warped & No \\
\hline \multirow[t]{2}{*}{$-\mathrm{Mg}$} & Young leaf & $\begin{array}{l}\text { Interveinal chlorosis, } \\
\text { then yellow entirely }\end{array}$ & Normal & Leaf margins warped & No \\
\hline & Old leaf & Light green entirely & Normal & Leaf margins warped & $\begin{array}{l}\text { light } \\
\text { brown spotting }\end{array}$ \\
\hline \multirow[t]{2}{*}{$-\mathrm{S}$} & Young leaf & Yellow or light green & $\begin{array}{l}\text { New leaf } \\
\text { smaller }\end{array}$ & Normal & No \\
\hline & Old leaf & Normal & Normal & Leaf margins warped & No \\
\hline
\end{tabular}

and other nutrient deficiency treatments. The leaves of entire seedlings became light yellow, and old leaves started fading at 30 days after treatment (DAT), followed by young leaves 10 days later, all leaves discolored at 50 DAT, and old leaves began to fall seriously from 60 DAT. Old leaves of $-\mathrm{P}$ seedlings became more dark green than those of control at 40 DAT, and margin at the middle part of leafs curled downward and appeared necrotic spotting, and withered later, while young leaves became light green at 60 DAT. Young leaves of $-\mathrm{K}$ seedlings became light green and smaller at 20 DAT, their old leaves were of interveinal chlorosis, and withered from tip to margin at 40 DAT.

Young leaves of $-\mathrm{Ca}$ seedlings became light green among leaf veins at 30 DAT, rolled upward at 50 DAT, and grew smaller later. On their old leaves occurred interveinal chlorosis at 40 DAT and then leave margins warped. Old 
leaves of $-\mathrm{Mg}$ seedlings were initially chlorotic on the tip at 30 DAT, as Mg deficiency aggravated, chlorotic area extended to leaf margin, then light brown necrotic spotting occurred and a few leaves fell. Their young leaves began to fade at 70 DAT, leaving an inverted Vshaped green area along the midrib on some leaves. And all leaves became light green finally. In $-\mathrm{S}$ treatment, the size of young leaves became smaller and their color faded yellow at 50 DAT; old leaves became light green at 70 DAT, their leaf margins warped and tip curled downward.

\section{Seedling growth performance}

There existed remarkable differences in height and diameter at root collar of $E$. fordii seedlings among all treatments (Figure 2). Among all six nutrient deficiency treatments, only $-\mathrm{N}$ and $-\mathrm{K}$ treatments showed their significant differences of seedling height from the control $(P$ $<0.05$ ), and $-\mathrm{N}$ and $-\mathrm{P}$ treatments were significantly different from the control in diameter at root collar. As shown in Figure 2, growth of $-\mathrm{N}$ seedlings were inhibited the most severely, and seedling height and diameter at root collar in $-\mathrm{N}$ treatment decreased $22.0 \%$ and $21.7 \%$ relative to the control, respectively. Seedling height of $-\mathrm{K}$ treatment was $13.6 \%$ lower than that of the control. And seedling diameter at root collar in $-\mathrm{P}$ treatment was $13.0 \%$ higher than that of the control.

From Figure 3 it was seen that the effects of nutrient deficiencies on biomass of leaf and root nodule were quite significant. $-\mathrm{N},-\mathrm{K}$ and $-\mathrm{Ca}$ treatments resulted in great reduction of leaf biomass, their leaf biomass were only $14.8 \%, 47.9 \%$ and $65.3 \%$ of that for the control, respectively; while no significant difference was seen between other three nutrient deficiency treatments $(-\mathrm{P},-\mathrm{Mg}$ and $-\mathrm{S})$ and the control. The great decreases of leaf biomass in $-\mathrm{N}$ and $-\mathrm{K}$ treatments were due to heavy defoliation at low part of seedlings in the two treatments. As to biomass of root nodules, $-\mathrm{N}$, $-\mathrm{P},-\mathrm{K}$ and $-\mathrm{S}$ treatments were quite different from the control. Their root nodule biomass were only $14.0 \%(-\mathrm{P})$ to $34.0 \%(-\mathrm{K})$ of that for the control (Figure 3), while $-\mathrm{Ca}$ and $-\mathrm{Mg}$ treatments did not differ from the control.

\section{Leaf nutrient interaction in seedlings}

It was shown in Figure 4 that concentrations of all macronutrients tested in leaves differed significantly among all nutrient deficiency treatments $(P>0.05)$. Leaf $\mathrm{N}$ concentrations in $-\mathrm{N}$ and -Ca seedlings were $33.2 \%$ and $32.2 \%$ lower than those in the control, respectively, while
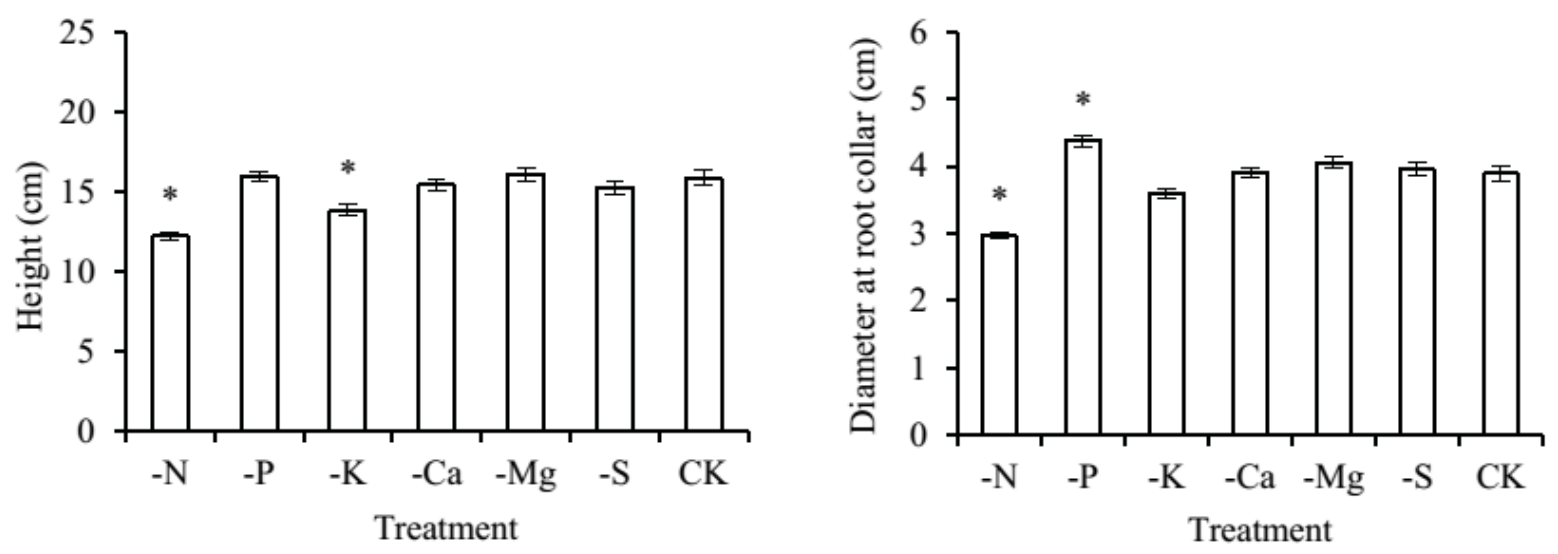

Figure 2 Height and diameter at root collar of Erythrophleum fordii seedlings under nutrient deficiency treatments $(-\mathrm{N},-\mathrm{P},-\mathrm{K},-\mathrm{Ca},-\mathrm{Mg},-\mathrm{S})$ compared with control $(\mathrm{CK}) .{ }^{*}$ refers to significant difference at 0.05 level between the nutrient deficiency treatment and control "all nutrient" 

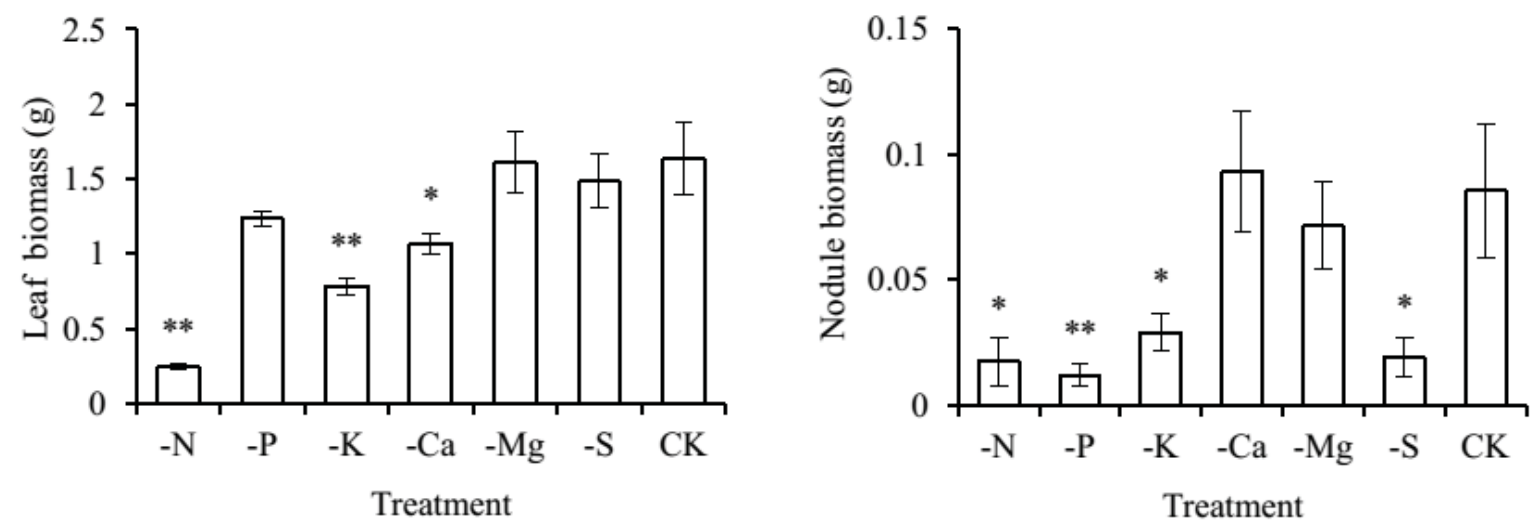

Figure 3Leaf and root nodule biomass of Erythrophleum fordii seedlings under nutrient deficiency treatments $(-\mathrm{N},-\mathrm{P},-\mathrm{K},-\mathrm{Ca},-\mathrm{Mg},-\mathrm{S})$ compared with control $(\mathrm{CK}) .{ }^{* *}$ and $*$ refer to significant differences between the nutrient deficiency treatment and the control at 0.01 and 0.05 levels, respectively

deficiencies of $\mathrm{P}, \mathrm{K}, \mathrm{Mg}$ and $\mathrm{S}$ seemed to have no significant effect on leaf $\mathrm{N}$ concentration. Leaf $\mathrm{P}$ concentrations in $-\mathrm{N}$ and $-\mathrm{K}$ seedlings were $145.2 \%$ and $80.0 \%$ higher than those in the control, respectively. Conversely, leaf $\mathrm{P}$ concentrations in $-\mathrm{S},-\mathrm{Mg}$ and $-\mathrm{Ca}$ seedlings were only $7.4 \%$ to $28.4 \%$ of those in the control. This inferred that there existed synergism between $\mathrm{P}$ and the three elements.

Leaf $\mathrm{K}$ concentrations in all nutrient deficiency treatments were all remarkably lower than those in the control. Leaf $\mathrm{K}$ concentration in $-\mathrm{K}$ seedlings were the lowest and remarkably decreased $92.8 \%$ relative to the control, the leaf $\mathrm{K}$ concentrations of all other nutrient deficiency treatments decreased $13.6 \%$ in $-\mathrm{Mg}$ seedlings to $50.1 \%$ in - Ca seedlings compared with the control. It was thus indicated that synergism between $\mathrm{K}$ and other five macronutrients were found in $E$. fordii seedlings.

All nutrient deficiency treatments resulted in significant increase of leaf $\mathrm{Ca}$ concentration relative to the control except $\mathrm{Ca}$ deficiency treatment (Figure 3). Among these treatments, effects of $\mathrm{K}$ and $\mathrm{S}$ deficiencies on leaf $\mathrm{Ca}$ concentration were the most significant, and leaf $\mathrm{Ca}$ concentrations in the two treatments increased $121.6 \%$ and $134.8 \%$, and leaf $\mathrm{Ca}$ concentrations in $-\mathrm{N},-\mathrm{P}$ and $-\mathrm{Mg}$ increased $26.8 \%, 35.6 \%$ and $32.0 \%$ relative to the con- trol, respectively. N, Ca and S deficiencies influenced significantly leaf $\mathrm{Mg}$ concentrations besides $\mathrm{Mg}$ deficiency. Leaf $\mathrm{Mg}$ concentrations in $-\mathrm{N},-\mathrm{Ca}$ and $-\mathrm{S}$ seedlings were $19.0 \%$ lower, and $17.8 \%$ and $38.6 \%$ higher than those in the control, respectively. While in $-\mathrm{P}$ and $-\mathrm{K}$ seedlings, leaf $\mathrm{Mg}$ concentrations were not different from that of the control. Leaf S concentrations in -P and - $\mathrm{K}$ seedlings were $22.8 \%$ lower and $52.0 \%$ higher than that of the control, and $\mathrm{N}, \mathrm{Ca}$ and $\mathrm{Mg}$ deficiency seemed to have no effect on leaf S concentration.

\section{Nutritional status in saplings}

Significant differences were seen between young and old leaves of saplings in concentrations of total $\mathrm{P}, \mathrm{K}, \mathrm{Ca}$ and $\mathrm{Mg}$ rather than total $\mathrm{N}$ and $\mathrm{S}$ (Table 4). Concentrations of total $\mathrm{P}$ and $\mathrm{K}$ in the young leaves were much higher than those in the old leaves, while concentration of total $\mathrm{Ca}$ in old leaves was higher than that in young leaves. These could further be well understood by ratio of their concentrations in young and old leaves, the ratio was near 1 for $\mathrm{N}$ and $\mathrm{S}$, more than 1.5 for $\mathrm{P}, \mathrm{K}$ and $\mathrm{Mg}$, and less than 0.5 for $\mathrm{Ca}$. 


\section{Discussion}

\section{Nutrient diagnosis for seedling}

Among all six macronutrient deficiency treatments, nitrogen deficiency had the most obvious influences on growth of $E$. fordii seedlings, which was in accordance with Betula alnoides (Chen et al. 2010) and Clerodendrum thomsoniae (Davis et al. 2011). This was due perhaps to the fact that amounts of nitrogen required for plants were greater than those of other mineral nutrients (Yoneyama et al. 2012), and nitrogen availability is thus a major limiting factor for plant growth. Nitrogen deficient resulted in heavy defoliation at low part of seedlings and great decrease of root nodule biomass. Leaf $\mathrm{N}$ concentrations and leaf biomass of $-\mathrm{N}$ seedlings decreased $33.2 \%$ and $85.2 \%$ in comparison with the control, which were a bit lower than those for $B$. alnoides seedlings (40.9\% and $91.4 \%$ ) under nitrogen deficiency (Chen et al. 2010), these difference might be due to that formation and function of $E$. fordii nodule could provide nitrogen to plant by nitrogenfixing like Medicago tuncatula (Tang et al. 2001), this phenomenon was also reviewed for legume by Bonilla \& Bolaños (2009).

-P seedlings showed light-green young leaves and dark green old leaves even with margin curled downward. And surprisingly, seedling diameter at root collar of -P treatment was significantly higher than that of the control. This is quite different from Chen et al.'s (2010) study on B. alnoides, in which phosphorus deficiency resulted in significant decrease of seedling height and root collar diameter. P deficiency also decrease mostly the root nodule biomass, since nodulation, nitrogen fixation are related directly with P supply (Zahran 1999). $P$ deficiency resulted in decreases of leaf $\mathrm{K}$ and $\mathrm{Ca}$ concentrations, while have no effects on leaf $\mathrm{N}, \mathrm{Mg}$ and $\mathrm{S}$ concentrations. This indicated that there existed possible antagonisms between $\mathrm{P}$ and $\mathrm{K}$ as well as $\mathrm{P}$ and Ca.
$\mathrm{K}$ deficiency decreased remarkably seedling height, leaf and root nodule biomass. The typical foliar symptoms of -K seedlings were interveinal chlorosis and withering from tip to margin. In $\mathrm{K}$ deficiency treatment, leaf $\mathrm{N}$ and $\mathrm{Mg}$ concentration almost equal to that in the control, while $\mathrm{P}, \mathrm{Ca}$ and $\mathrm{S}$ concentration increased significantly (Figure 3). This inferred that function of potassium in plant would be complemented partly by other elements since potassium is of great importance as an osmolyte for adaptation (Bonilla \& Bolaños 2009, Gajdanowicz et al. 2010, Battie-Laclau et al. 2013).

$\mathrm{Ca}$ deficiency had no effects on seedling growth and root nodule biomass, while decreased leaf biomass significantly. Young leaves of -Ca seedlings turned light green and small as well as rolled upward. P was the major limited factor in $\mathrm{Ca}$ deficiency treatment, and leaf $\mathrm{P}$ concentration decreased more sharply than leaf $\mathrm{Ca}$ concentration in $-\mathrm{Ca}$ seedlings in comparison with the control (Figure 3). This may be due to that both $\mathrm{P}$ and $\mathrm{Ca}$ were essential nutrients in metabolism of rhizobia (O'Hara 2001). Ca deficiency also influenced negatively the absorption of $\mathrm{N}$ and $\mathrm{K}$, while positively for that of $\mathrm{Mg}$. Such interactions between $\mathrm{Ca}$ and other macronutrients were quite different from those for non-N-fixing species such as B. alnoides (Chen et al. 2010).

$\mathrm{Mg}$ deficiency had no significant influence on seedling growth, and leaf and root nodule biomass in the present study. Inverted V-shape green area along the midrib on young leaf was the typical symptom of $-\mathrm{Mg}$ seedlings. $\mathrm{Mg}$ deficiency decreased greatly concentrations of leaf $\mathrm{P}$ and $\mathrm{K}$ besides $\mathrm{Mg}$, while increased that of leaf $\mathrm{Ca}$.

$-\mathrm{S}$ seedlings demonstrated yellow small young leaves and their old leaves turned light green with margin wrapped and tip curled downward, the symptom was mostly like combination of $\mathrm{K}$ and $\mathrm{P}$ deficiencies. This was supported by the fact that $\mathrm{S}$ deficiency decreased greatly concentrations of leaf $\mathrm{P}$ and $\mathrm{K}$, and in- 
creased significantly concentrations of leaf $\mathrm{Ca}$ and $\mathrm{Mg}$. S deficiency did not influence seedling height, diameter at root collar, leaf biomass, while decreased remarkably root nodule biomass during the study period.

\section{Nutrient diagnosis for young plantation}

Leaves of $E$. fordii saplings in the young plantations at Shaoguan, Guangdong Province displayed chlorosis at tip and margin with leaf margin rolling upward, and discoloration and deformation on young leaves were much more obvious than on old leaves (Figure 1). The color and shape changes of both young and old leaves on the saplings were similar to leaf symptoms of seedlings under $\mathrm{Ca}, \mathrm{Mg}$ and $\mathrm{S}$ deficiencies, for an example, young leaves on the saplings were of interveinal chlorosis from leaf tip and margin leaving an inverted $\mathrm{V}$-shaped green area along main vein, old leaves were yellow with main vein only being green (Figure 1), these were similar to leaf symptoms of seedlings under $\mathrm{Mg}$ deficiencies. It could thus be determined preliminarily from leaf symptoms that they might suffer from $\mathrm{Ca}$, $\mathrm{Mg}$ or S deficiencies simultaneously.
As for nutrient aspect, concentrations of $\mathrm{N}$, $\mathrm{P}, \mathrm{K}$ and $\mathrm{Mg}$ are significantly higher in new or young leaves than in old leaves under deficiencies of these elements whichs are usully mobile element, and vice versa for those of $\mathrm{Ca}$ and S which are immobile (Ares et al. 2003, Maathuis \& Diatloff 2013). In the present study, $\mathrm{P}, \mathrm{K}$ and $\mathrm{Mg}$ concentrations were significantly higher, and $\mathrm{Ca}$ concentration lower in young leaves than in old leaves, while $\mathrm{N}$ and $\mathrm{S}$ concentrations were not significantly different between young and old leaves of $E$. fordii saplings (Table 4). Therefore the young plantations suffered from $\mathrm{P}, \mathrm{K}, \mathrm{Mg}$ and $\mathrm{Ca}$ deficiencies rather than $\mathrm{N}$ and $\mathrm{S}$ deficiencies. It was reported that base cations such as $\mathrm{K}^{+}, \mathrm{Ca}^{2+}$, $\mathrm{Mg}^{2+}$ would be lost seriously when $\mathrm{pH}$ was below 5 (Bigelow \& Canham 2007, Nawaza et al. 2012), this was also confirmed in Guan and Wei's (2013) study in which more than $70 \%$ of $\mathrm{Ca}^{2+}$ and $\mathrm{Mg}^{2+}$ was lost by acid rain in northern part of Guangdong Province. It is noteworthy that $\mathrm{Al}$ toxicity, usually occurs when soil $\mathrm{pH}$ value is below 5 (Rout et al. 2001), can interfere uptake of $\mathrm{P}, \mathrm{K}, \mathrm{Ca}$ and $\mathrm{Mg}$ (Roy et al. 1988, Schaedle et al. 1989), which may also result in reductions of their concentration in
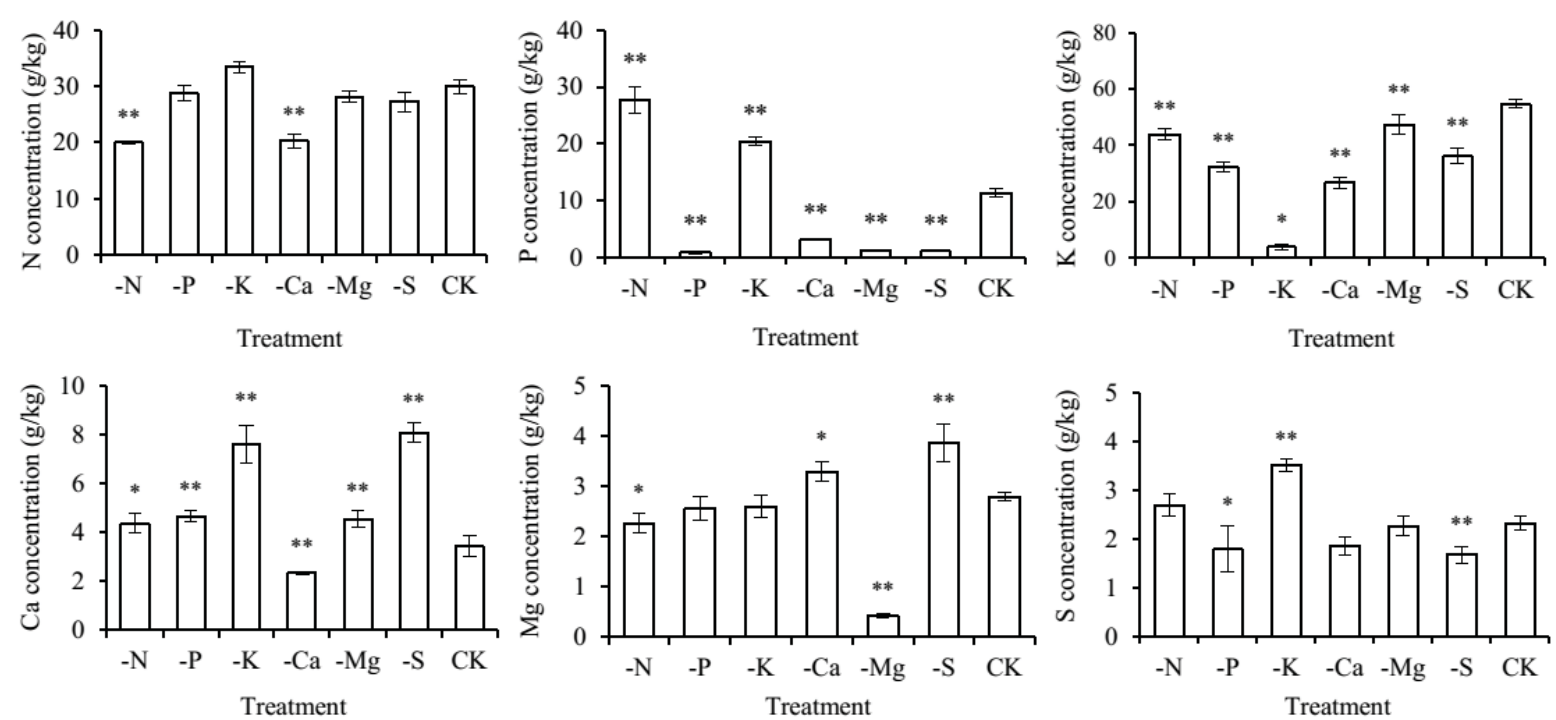

Figure 4Leaf nutrient concentrations of Erythrophleum fordii seedlings under nutrient deficiency treatments $(-\mathrm{N},-\mathrm{P},-\mathrm{K},-\mathrm{Ca},-\mathrm{Mg},-\mathrm{S})$ compared with control $(\mathrm{CK}) .{ }^{* *}$ and * refers to significant differences between the nutrient deficiency treatment and the control at 0.01 and 0.05 levels, respectively 
Table 4 Leaf macronutrient concentration $\left(\mathrm{g} \cdot \mathrm{kg}^{-1}\right)$ of saplings with deficiency symptoms in Erythrophleum fordii plantation

\begin{tabular}{lllllll}
\hline Position & $\mathrm{N}$ & $\mathrm{P}$ & $\mathrm{K}$ & $\mathrm{Ca}$ & $\mathrm{Mg}$ & $\mathrm{S}$ \\
\hline Young leaves & $18.92( \pm 2.57)$ & $1.74( \pm 0.22)$ & $8.67( \pm 1.41)$ & $1.61( \pm 0.68)$ & $0.68( \pm 0.16)$ & $1.30( \pm 0.23)$ \\
Old leaves & $19.03( \pm 3.54)$ & $0.99( \pm 0.14)$ & $4.29( \pm 0.42)$ & $7.19( \pm 2.69)$ & $0.44( \pm 0.22)$ & $1.29( \pm 0.21)$ \\
$t$-test & $-0.07^{\mathrm{ns}}$ & $9.93^{* *}$ & $10.76^{* *}$ & $-5.26^{* *}$ & $2.39^{*}$ & $0.14^{\mathrm{ns}}$ \\
$\begin{array}{l}\text { Young/Old } \\
\text { leaves }\end{array}$ & $0.99( \pm 0.25)$ & $1.75( \pm 0.27)$ & $2.02( \pm 0.23)$ & $0.22( \pm 0.19)$ & $1.55( \pm 1.01)$ & $1.01( \pm 0.21)$ \\
\hline
\end{tabular}

Note. Abbreviation: ns, no significant; * $P<0.05 ;{ }^{* *}, P<0.01$.

leaves and displaying leaf symptoms. As the soil $\mathrm{pH}$ was about 4.3 at the site, probability of Al toxicity should be taken into consideration. However, the content of exchangeable aluminum was about $4.5 \mathrm{cmol}(+) \cdot \mathrm{kg}^{-1}$ in layer $0-10$ $\mathrm{cm}$, and below $3.5 \mathrm{cmol}(+) \cdot \mathrm{kg}^{-1}$ in deeper layers, the risk of Al toxicity was perhaps a bit low (Álvarez et al. 2005). On the other hand, the soil fertility seems to be very poor, particular with quite low contents of $\mathrm{P}, \mathrm{Ca}$ and $\mathrm{Mg}$ as compared to results in monograph Guangdong Soil (Liu 1993), these supported the findings about nutrient diagnosis mentioned above. As a whole, it was demonstrated that our results for diagnostic tests of macronutrient deficiencies for seedlings could also be applied in analysis on nutrient status of saplings, and could guide nutrient management in young plantations for E. fordii.

\section{Conclusions}

$\mathrm{N}$ deficiency demonstrated the most obvious foliar symptoms, and decreased greatly height, diameter at root collar, and leaf and root nodule biomass of E. fordii seedling among six macronutrient deficiency treatments, while the growth inhibition degree seemed to be less than that for non-N-fixing species. P deficiency could increase significantly diameter at root collar, and decrease seedling height and root nodule biomass. And $\mathrm{P}$ was the major limiting factor under deficiencies of $\mathrm{Mg}, \mathrm{Ca}$ and $\mathrm{S}$, which indicated that $\mathrm{P}$ play an important role in nutrient demand and balance for E. fordii. There existed widely antagonism or synergism between these macronutrients, especially for $\mathrm{P}, \mathrm{K}$ and $\mathrm{Ca}$, leaf concentration of these three elements were significantly higher or lower in all deficiency treatments than those of the control. Our findings about nutrient diagnosis for seedling could also be used for saplings in the practice of plantation nutritional management.

\section{Acknowledgements}

This study was financially supported by Special Research Program for Public-welfare Forestry (No. 201204301-2) and National Nonprofit Institute Research Grant of RITF (No. RITFKYYW2010-05). We would like to thank Mrs. Le-Su Yang and Mrs. Bin Yu for their nutrient determinations.

\section{References}

Álvarez E., Fernández-Marcos M.L., Monterroso C., Fernández-Sanjurjo M.J., 2005. Application of aluminum toxicity indices to soils under varous forest species. Forest Ecology and Management 211: 227-239. DOI: 10.1016/j.foreco.2005.02.044.

Ares A., Falcao N., Yuyama K., Yost R.S., Clement C.R., 2003. Response to fertilization and nutrient deficiency diagnostics in peach palm in Central Amazonia. Nutrient Cycling in Agroecosystems 66: 221-232. DOI: 10.1023/A:1024458823052.

Battie-Laclau P., Laclau J.P., Piccolo M.C., Arenque B.C., Beri C., Mietton L., Muniz M.R.A., Jordan-Meille L., Buckeridge M.S., NouvellonY., Ranger J., Bouillet J.P., 2013. Influence of potassium and sodium nutrition on 
leaf area components in Eucalyptus grandis trees. Plant and Soil 371: 19-35. DOI: 10.1007/s11104-013-16637.

Bigelow S.W., Canham C.D., 2007, Nutrient limitation of juvenile trees in a northern hardwood forest: Calcium and nitrate are preeminent. Forest Ecology and Management 243: 310-319. DOI: 10.1016/ j.foreco.2007.03.027.

Bonilla I., Bola-os L., 2009. Mineral nutrition for legumerhizobia symbiosis: $\mathrm{B}, \mathrm{Ca}, \mathrm{N}, \mathrm{P}, \mathrm{S}, \mathrm{K}, \mathrm{Fe}, \mathrm{Mo}, \mathrm{Co}$, and Ni: a review. in Lichtfouse E. (ed). Organic farming, pest control and remediation of soil pollutants, Sustainable Agriculture Reviews, volume 1: 253-274. DOI 10.1007/978-1-4020- 9654-9_13, Springer Science + Business Media B.V.

Chen L., Zeng J., Jia H.Y., Zeng J., Guo W.F., Cai D.X., 2012. Growth and nutrient uptake dynamics of Mytilaria laosensis seedlings under exponential and conventional fertilizations. Soil Science and Plant Nutrition 58: 618-626. DOI: 10.1080/00380768.2012.708879.

Chen L., Zeng J., Xu D.P., Zhao Z.G., Guo J.J., 2010. Macronutrient deficiency symptoms in Betula alnoides seedlings. Journal of Tropical Forest Science 22: 403-413.

Danso S.K.A., Bowen G.D., Sanginga N., 1992. Biological nitrogen fixation in trees in agro-ecosystems. Plant and Soil 141: 177-196. DOI: 10.1007/BF00011316.

Davis K.I., Niedziela Jr C.E., Reddy M.R., Whipker B.E., Frantz J., 2011. Nutrient disorder symptomology and foliar concentrations of Clerodendrum thomsoniae. Journal of Plant Nutrition 34: 1079-1086. DOI: 10.108 0/01904167.2011.555805.

Fageria V.D., 2001. Nutrient interactions in crop plants. Journal of Plant Nutrition 24: 1269-1290. DOI: 10.1081/ PLN-100106981.

Gajdanowicz P., Michard E., Sandmann M., Rocha M., Corrêa L.G.G., Ramírez-Aguilar S.J., Gomez-Porras J.L., Gonzáleza W., Thibaud J.B., van Dongen J.T., Dreyer I., 2010. Potassium $(\mathrm{K}+)$ gradients serve as a mobile energy source in plant vascular tissues. PNAS 108: 864-869. DOI: 10.1073/pnas.1009777108.

Guan G.C., Wei X.H., 2103. Simulation experiment on effect of soils Calcium and Magnesium ions losses on natural rainfall in Karst rocky area of north Guangdong. Journal of Soil and Water Conservation 27 (5): 76-79, 86. [In Chinese].

Liu A.S.(editor), 1993. Guangdong soil. Guangdong Soil General Investigation Office. Beijing: Science Publish House. [In Chinese].

Lu J.K., Kang L.H., He X.H., Xu D.P., 2011. Multilocus sequence analysis of the Rhizobia from five woody legumes in southern China. African Journal of Microbiology Research 5: 5343-353.

Maathuis F.J.M., Diatloff E., 2013. Roles and functions of plant mineral nutrients. In Maathuis F.J.M. (ed.), Plant mineral nutrients: methods and protocols, methods in molecular biology, vol. 953: 1-21. DOI 10.1007/9781-62703-152-3_1, Springer Science+Business Media,
LLC.

Millner J.P., Kemp P.D., 2012. Foliar nutrients in Eucalyptus species in New Zealand. New Forests 43: 255-266. DOI: 10.1007/s11056-011-9279-3.

Mortimer P.E., Le Roux M.R., Pérez-Fernández M.A., Benedito V.A., Kleinert A., Xu J., Valentine A.J., 2013. The dual symbiosis between arbuscular mycorrhiza and nitrogen fixing bacteria benefits the growth and nutrition of the woody invasive legume Acacia cyclops under nutrient limiting conditions. Plant and Soil 366: 229-241. DOI: 10.1007/s11104-012-1421-2.

Nawaza R., Parkpiana P., Garivaitb H., Anurakpongsatornc P., DeLauned R.D., Jugsujindad A., 2012. Impacts of acid rain on base cations, aluminum, and acidity development in highly weathered soils of Thailand. Communications in Soil Science and Plant Analysis 43: 1382-1400. DOI: 10.1080/00103624.2012.670347.

Nghia N.H., 2004. Status of forest genetic resources conservation and management in Vietnam. In: Luoma-aho T., Hong L.T., Ramanatha V., Sim H.C. (eds), Forest genetic resources conservation and management. Serdang, Malaysia: IPGRI-APO. 290-301.

O'Hara G.W., 2001. Nutritional constraints on root nodule bacteria affecting symbiotic nitrogen fixation: a review. Australian Journal of Experimental Agriculture 41: 417-433. DOI: 10.1071/EA00087.

Ouimet R., Moore J.D., Duchesne L., Camiré C., 2013. Etiology of a recent white spruce decline: role of potassium deficiency, past disturbances, and climate change. Canadian Journal of Forest Research 43: 66-77. DOI: 10.1139/cjfr-2012-0344.

Rout G.R., Samantaray S., Das P., 2001. Aluminum toxicity in plants: a review. Agronomie 21: 3-21. DOI: 10.1051/agro:2001105.

Roy A.K., Sharma A., Talukder G., 1988. Some aspects of aluminum toxicity in plants. The Botanical Review 54: 146-178. DOI: 10.1007/ BF02858527.

Schaedle M., Thornton F.C., Raynal D.J., Tepper H.B., 1989. Response of tree seedlings to aluminum. Tree Physiology 5: 337-356. DOI: 10.1093/ treephys/5.3.337.

Scheublin T.R., Ridgway K.P., Young J.P.W., Heijden M.G.A., 2004. Nonlegumes, legumes, and root nodules harbor different arbuscular mycorrhizal fungal communities. Applied Environment Microbiology 70: 6240 6246. DOI: 10.1128/AEM.70.10.6240-6246.2004.

Schulze J.H., Temple G., Temple S.J., Beschow H., Vance C.P., 2006. Nitrogen fixation by white lupin under phosphorus deficiency. Annals of Botany 98: 731-740. DOI: 10.1093/aob/mcl154.

Tang C., Hinsinger P., Drevon J.J., Jaillard B., 2001. Phosphorus deficiency impairs early nodule functioning and enhances proton release in roots of Medicago tuncatula L. Annals of Botany 88: 131-138. DOI: 10.1006/ anbo.2001.1440.

Walters D.R., Bingham I.J., 2007. Influence of nutrition on disease development caused by fungal pathogens: implications for plant disease control. Annals of Ap- 
plied Biology 151: 307-324. DOI: 10.1111/j.17447348.2007.00176.x.

Yao Y., Wang R., Lu J.K., Sui X.H., Wang E.T., Chen W.X., 2014. Genetic diversity and evolution of Bradyrhizobium populations nodulating Erythrophleum fordii, an evergreen tree indigenous to the southern subtropical region of China. Applied and Environmental Microbiology 80: 6184-6194. DOI: 10.1128/AEM.01595-14.

Yeh D.M., Lin L., Wright C.J., 2000. Effects of mineral nutrient deficiencies on leaf deveolpment, visual symptoms and shoot-root ratio of Spathiphyllum. Scientia Horticulturae 86: 223-233. DOI: 10.1016/S03044238(00)00152-7.

Yoneyama K., Xie X.N., Kim H., Kisugi T., Nomura T., Sekimoto H., Yokota T., Yoneyama K., 2012. How do nitrogen and phosphorus deficiencies affect strigolactone production and exudation? Planta 235: 1197-1207. DOI: $10.1007 / \mathrm{s} 00425-011-1568-8$.

Zahran H.H., 1999. Rhizobium-legume symbiosis and nitrogen fixation under severe conditions and in an arid climate. Microbiology and Molecular Biology Reviews 63: 968-989.

Zhao Z.G., Guo J.J., Sha E., Zeng J., Xu J.M., 2012. Natural distribution, endangered mechanism and conservation strategy of an endangered tree species, Erythrophleum fordii Oliv. In: Sim Heok-Choh, Syuqiyah Abdul Hamid, Li Mei (eds.), Multinational and transboundary conservation of valuable and endangered forest species. IUFRO World Series, Volume 30: 113-116. 